\title{
Marjanviljelystä vahva elinkeino Pohjois-Suomeen -hanke kehittää pohjoista marjanviljelyä
}

\author{
Kalle Hoppula $^{1)}$, Markku Kajalo ${ }^{2)}$, Kati Hoppula ${ }^{1)}$, Marja Uusitalo ${ }^{3)}$, Risto Tahvonen ${ }^{4)}$ ja Kirsti Voho ${ }^{5)}$ \\ ${ }^{1)}$ MTT Sotkamo,Kipinäntie 16, 88600 Sotkamo, kalle.hoppula@mtt.fi, kati.hoppula@mtt.fi \\ ${ }^{2)}$ Oulun yliopisto, Kajaanin yliopistokeskus, Biotekniikan laboratorio, Salmelantie 43, 88600 Sotkamo, \\ markku.kajalo@oulu.fi \\ ${ }^{3}$ MTT Rovaniemi, Eteläranta 55, 96300 Rovaniemi, marja.uusitalo@mtt.fi \\ ${ }^{4)}$ MTT Piikkiö, Toivonlinnantie 518, 21500 Piikkiö, risto.tahvonen@mtt.fi \\ ${ }^{5)}$ ProAgria Oulu, PL 106, 90101 Oulu, kirsti.voho@roagria.fi
}

\section{Tiivistelmä}

Pohjois-Suomi eli Kainuun, Pohjois-Pohjanmaan ja Lapin maakunnat ovat marjanviljelyn alituotantoaluetta ja alueella olisikin tilaa nykyistä huomattavasti laajemmalle marjanviljelylle. Yhdessä Ruotsin ja Norjan pohjoisosien kanssa alue on maailman pohjoisinta marjanviljelyaluetta ja siksi alueella tarvitaan erityistietoa pohjoisiin olosuhteisiin soveltuvista viljelymenetelmistä ja lajikkeista.

MTT, Oulun yliopisto ja ProAgria Oulu toteuttavat alueella hanketta ”Marjanviljelystä vahva elinkeino Pohjois-Suomeen", jonka puitteissa Pohjois-Suomen alueella testataan uusia marjanviljelymenetelmiä ja marjalajikkeita sekä tuotetaan tietoa viljelyn taloudesta. MTT:n tehtävänä on tuottaa kenttäkokeissa biologista ja viljelyteknistä tietoa, Oulun yliopisto tuottaa MTT:n kokeiden pohjalta tuotantokustannuslaskelmia ja ProAgria Oulu vastaa tiedon siirtymisestä alueen viljelijöille.

Hankkeessa tehdään lajikekokeita mansikalla, vadelmalla, musta-, viher- ja valkoherukalla, pensasmustikalla. Mansikalla ja vadelmalla tutkitaan kausihuoneviljelyä sekä kastelua ja lannoitusta, mansikalla tabletop- eli pöytäviljelyä ja mustaherukalla eri tuotantopanosten vaikutusta viljelyn kannattavuuteen. Lisäksi hanke tekee pienimuotoista lajikekoetoimintaa erikoismarjoilla. Kokeet tehdään MTT:n Sotkamon, Ruukin ja Rovaniemen tutkimusasemilla.

Hanketta hallinnoi MTT:n Puutarhakasvit -tutkimusryhmä MTT Sotkamon tutkimusasemalta käsin. Hanketta rahoitetaan EU:n Maaseuturahastosta Kainuun, Pohjois-Pohjanmaan ja Lapin TE-keskusten kautta. Hankkeen kesto on 27.3.2008-28.2.2012 ja kokonaisbudjetti on 545849 euroa. Hankkeelle ovat antaneet lisäksi materiaalisponsorointia Puutarha Tahvoset Oy, Marja-Suomen Taimituotanto Oy, Kekkilä Oyj ja R. Laaksonen Oy.

\author{
Asiasanat \\ Marjanviljely, lajikkeet, viljelymenetelmät.
}




\section{Pohjoisessa marjanviljelyssä on kehittämispotentiaalia}

Pohjois-Suomi eli Kainuun, Pohjois-Pohjanmaan ja Lapin maakunnat ovat marjanviljelyn alituotantoaluetta ja alueella olisikin tilaa nykyistä huomattavasti laajemmalle marjanviljelylle. Yhdessä Ruotsin ja Norjan pohjoisosien kanssa alue on maailman pohjoisinta marjanviljelyaluetta ja siksi alueella tarvitaan erityistietoa pohjoisiin olosuhteisiin soveltuvista viljelymenetelmistä ja lajikkeista.

MTT, Oulun yliopisto ja ProAgria Oulu toteuttavat alueella hanketta "Marjanviljelystä vahva elinkeino Pohjois-Suomeen", jonka puitteissa Pohjois-Suomen alueella testataan uusia marjanviljelymenetelmiä ja marjalajikkeita sekä tuotetaan tietoa viljelyn taloudesta. Hankkeen tarkoituksena on tietoa tuottamalla vahvistaa alueella olevaa marjanviljelyä ja luoda parempia mahdollisuuksia uusien viljelmien käynnistämiselle.

MTT:n tehtävänä hankkeessa on tuottaa kenttäkokeissa biologista ja viljelyteknistä tietoa, Oulun yliopisto tuottaa MTT:n kokeiden pohjalta tuotantokustannuslaskelmia ja ProAgria Oulu vastaa tiedon siirtymisestä alueen viljelijöille. Hanketta hallinnoi MTT:n Puutarhakasvit -tutkimusryhmä MTT Sotkamon tutkimusasemalta käsin. Hanketta rahoitetaan EU:n Maaseuturahastosta Kainuun, Pohjois-Pohjanmaan ja Lapin TE-keskusten kautta. Hankkeen kesto on 27.3.2008-28.2.2012 ja kokonaisbudjetti on 545849 euroa. Hankkeelle ovat antaneet lisäksi materiaalisponsorointia Puutarha Tahvoset Oy, Marja-Suomen Taimituotanto Oy, Kekkilä Oyj ja R. Laaksonen Oy.

Hankkeessa tehdään lajikekokeita mansikalla, vadelmalla, musta-, viher- ja valkoherukalla, pensasmustikalla. Mansikalla ja vadelmalla tutkitaan kausihuoneviljelyä sekä kastelua ja lannoitusta, mansikalla tabletop- eli pöytäviljelyä ja mustaherukalla eri viljelytoimenpiteiden poistamisen vaikutusta. Lisäksi hanke tekee pienimuotoista lajikekoetoimintaa erikoismarjoilla. Kokeet tehdään MTT:n Sotkamon, Ruukin ja Rovaniemen tutkimusasemilla.

\section{Lisää lajikkeita nykyisten rinnalle}

Pohjois-Suomessa nykyisin viljeltävä marjalajikevalikoima on erittäin pieni ja tavoitteenamme on löytää uusia vaihtoehtoja nykyisten rinnalle. Merkittävimmät marjojen lajikevalikoimaa rajoittavat tekijät ovat talvenkestävyys sekä kyky tuottaa kukka-aiheita pohjoisissa ilmasto- ja valo-olosuhteissa.

Lajikekokeita tehdään mansikalla, vadelmalla, musta-, valko- ja viherherukalla sekä pensasmustikalla. Kokeet on perustettu Sotkamoon ja Rovaniemelle vuosina 2008 ja 2009 sekä Ruukkiin vuonna 2009. Mansikalla kokeillaan MTT:n omia uusia lajikkeita, uutuuslajikkeita ja jalosteita Norjasta, Hollannista, Kanadasta ja Ruotsista. Verranteina ovat vuonna 2008 valiotaimituotannossa olleet lajikkeet. Yhteensä testattavia mansikkalajikkeita on 25.

Herukoilla lajikekokeissa on MTT:n oman jalostusohjelman kaksi uutta viherherukkalajike-ehdokasta, kaksi uutta valkoherukkalajike-ehdokasta sekä neljä mustaherukkalajike-ehdokasta. Lisäksi kokeissa on norjalaisia lajikkeita sekä verranteina nykyiset tärkeimmät viljelylajikkeet. Yhteensä testattavia herukkalajikkeita on 15.

Vadelmalla lajikekokeissa on mukana perinteisten Suomessa myytyjen lajikkeiden lisäksi mukana lajikkeita mm. Venäjältä, Skotlannista ja Unkarista. Yhteensä vadelmalajikkeita on mukana 20. Pensasmustikan lajikekokeissa mukana ovat MTT:n jalostamat nykyiset viljelylajikkeet ja lajikeuutuudet sekä kaksi amerikkalaista lajiketta, yhteensä 11 lajiketta.

Ensimmäiset tulokset mansikan lajikekokeista on saatu kesällä 2008, jolloin satoa tuottivat kotimaiset uutuuslajikkeet ja verrannelajikkeet. Vuonna 2010 satoa aletaan saada myös ulkomaisista uutuuslajikkeista, jotka pääosin istutettiin vasta 2009. Vadelmalla ja pensasmustikalla varsinainen sadontuotto alkaa 2010, vaikka 2009 niiltä poimittiin jo pieniä satomääriä. Herukoiden sadontuotto alkaa myös 2010.

Edellä mainittujen lajikekokeiden lisäksi hankkeen puitteissa on vuosina 2008 ja 2009 seurattu pienellä intensiteetillä MTT Sotkamossa olevia 2006-2007 perustettuja mesimarjan, lakan, kuukausimansikan ja omenan lajikekokeita.

\section{Uusia viljelymenetelmiä kokeillaan}

Kausihuone- eli tunneliviljely on yleistynyt viime vuosina Euroopassa nopeasti. Kausihuoneella tarkoitetaan kevyttä, siirrettävää kasvihuonetta, jonka voi rakentaa olemassa olevan kasvuston päälle ja jonka katemuovi otetaan talveksi pois siten, että ainoastaan tukirakenteet ovat talvisin paikallaan. Kausihuonetuotannolla saadaan pidennettyä kasvukautta sekä keväällä että syksyllä, päästään parempaan tuotantovarmuuteen sään aiheuttamien riskien vähentyessä ja kemiallista harmaahomeen torjuntaa voidaan vähentää merkittävästi. Toisaalta investointi on kallis, tarvikekulut neliömetriä kohden noin viidestä eurosta ylöspäin. 
Tabletop- eli pöytäviljelyllä tarkoitetaan mansikan taimien kasvattamista poimintakorkeudelle nostetussa kasvualustassa, yleisimmin turpeessa. Menetelmä on yleistymässä Keski-Euroopassa maalevintäisten kasvitautien aiheuttamien ongelmien vuoksi. Maalevintäiset kasvitaudit eivät tällä tavalla viljeltäessä aiheuta merkittäviä ongelmia, koska kasvualusta voidaan vaihtaa edellisen saastuttua. Tällä tavoin ei viljelykierrossa myöskään tarvita välivuosia, vaan mansikkaa voidaan vuodesta toiseen viljellä samalla paikalla, mikä on eduksi, jos tilalla on peltomaasta pulaa. Menetelmän ongelmina ovat käsityövaltaisuus ja korkeat investointikulut.

MTT:n Sotkamon, Ruukin ja Rovaniemen tutkimusasemille rakennettiin keväällä ja alkukesästä 2009 samanlaiset noin 250 neliömetrin kausihuoneet, joissa kokeillaan mansikan tuotantoa maassa ja pöydillä sekä vadelman tuotantoa maassa. Ruukissa mansikkakokeet perustettiin 2009 Hollannista tuoduista odotuspetitaimista neljällä eri lajikkeella. Sotkamossa ja Rovaniemellä mansikkakokeet maahan perustettiin vuonna 2008 eli vuosi ennen kausihuoneiden rakentamista kotimaisilla rönsytaimilla kolmella eri lajikkeella ja mansikkakokeet pöydille vuonna 2009 Hollannista tuoduista odotuspetitaimista neljällä eri lajikkeella. Vadelmakokeet perustettiin kahdeksalla lajikkeella Sotkamoon ja Rovaniemelle vuonna 2008 ja Ruukkiin vuonna 2009. Kokeissa selvitetään, millaisia hyötyjä, haittoja ja haasteita kausihuone- ja pöytäviljelystä aiheutuu Pohjois-Suomessa.

Mustaherukan tuotanto nousee ja laskee maailmanmarkkinoiden mukana. 2000-luvulla tuotannon kannattavuus on useina vuosina ollut keskimäärin heikko kansainvälisen ylituotannon painaessa tuottajahinnat tuotantokustannuksia alemmalle tasolle. Mustaherukalla testataan tuotantopanosten lisäämisen vaikutusta viljelyn kannattavuuteen. Kokeissa on testattavat käsittelyt ovat muovikate ja ei muovikatetta, tihkukastelu ja ei kastelua, kastelulannoitus ja rakeinen lannoitus sekä näiden eri yhdistelmät. Kokeet on perustettu Sotkamoon ja Rovaniemelle 2008 sekä Ruukkiin 2009.

Mansikan kastelu ja lannoitus on Suomessa ohjeistettu Etelä-Suomesta saatujen tutkimustulosten perusteella. Pohjois-Suomessa nämä suositukset eivät välttämättä toimi, koska esimerkiksi talvi on ankarampi ja kevät sekä syksy lyhempiä. Hankkeen kokeissa testataan erilaisia mansikan kastelu- ja lannoitusstrategioita kokeissa, jotka perustettu Sotkamoon ja Rovaniemelle 2008 sekä Ruukkiin 2009.

\section{Tieto euroiksi ja toimialan hyväksi}

MTT:n tutkimusasemilta saatavien koetulosten perusteella Kajaanin yliopistokeskuksen Biotekniikan laboratoriossa tehdään eri viljelykasveille ja tuotantomenetelmille tuotantokustannuslaskelmat. Tarvittavilta osin hankkeessa tehdään myös investointilaskelmia, esimerkkinä kausihuoneen hankinta. Koska hankkeessa saadaan koetuloksia useilta eri lajikkeilta ja eri viljelymenetelmiltä kolmella erilaisella koepaikalla (Sotkamo, Ruukki, Rovaniemi), voidaan hankkeen tulosten perusteella arvioida tilakohtaisesti viljelyn tuotantokustannuksia monipuolisesti useat eri tekijät huomioiden.

Marjanviljelystä vahva elinkeino Pohjois-Suomeen -hankkeen tehtäviin kuuluu tiedon tuottamisen lisäksi myös tiedon siirtäminen yrittäjille ja alan toimijoille. Tulokset siirretään Pohjois-Suomen ProAgrioiden neuvojille viljelyneuvonnan tueksi ja hanke siirtää tietoa suoraan toimialalle myös tiedotustilaisuuksien, lehtiartikkelien ja internetin avulla. 